\title{
Effect of administration two dose ofHuman chorionic gonadotropin and combination between human chorionic gonadotropin and flunixin meglumine on pregnancy rates in repeat breeders cross breed cows.
}

\author{
${ }^{1}$ Jawad K. Taher . ${ }^{2}$ Khawla A. Hussein \\ 1’2Department of surgery and obstetrics, College veterinary medicine, university of Baghdad, Iraq. \\ Email: drjawadkadhim@gmail.com \\ Email:khawlaabbasshussein@gmail.com
}

\begin{abstract}
The aim of the current study is to treat cases of repeat breeder in crossbreed cows and to improve pregnancy rate in affected cows. The study divided the number of animals into four groups, group $(10=\mathrm{T} 1)$, where the first group gave human chorionic gonadotropin on the day of oestrus and repeated the same dose 1500 IU Five days postinsemination and the group $(\mathrm{T} 2=10)$ where the hCG hormone was given at a dose of $1500 \mathrm{IU}$ on the day of the estrus and Flunxin meglumine treatment with a dose $(2 \mathrm{ml} / 50 \mathrm{~kg} \mathrm{~b} . \mathrm{w})$ each $\mathrm{ml}$ contain to (50 $\mathrm{mg}$ of FM) from the fifth day post insemination for three days and the third group, which numbered 5 cows in the group $(\mathrm{C} 1=5)$, were considered a control group without treatment, while the fourth group $(\mathrm{C} 2=5)$ is considered fertile cows, the purpose of their presence in the study is to evaluate the effectiveness of the fertility of the semen straws used in the study. The study showed that the pregnancy rate in cows in the groups, respectively, is $40 \%, 60 \%, 0 \%, 60 \%$. The statistical analysis showed that there were significant differences at $(\mathrm{P}<0.01)$ between the treated and fertile groups and the untreated group, which means an improvement in the pregnancy rate in treated cows that were suffering from repeat breeding. Early pregnancy was diagnosed rectally using ultrasound
\end{abstract}

Keyword: hCG , FM , PREGNANCY RATE , REPEAT BREEDER

\section{Introduction}

The term repeat breeder or repeat breeder syndrome has been coined to describe cows that failed to conceive after three or more inseminations. Repeat breeding is an important factor involved in infertility, which has become a major source of economic losses in the cattle industry due to the need for more insemination, reduced milk production, increased calving interval and increased culling rates (Parkinson, T. J. 2001). Failure of fertilization and early embryonic death are two main reasons 
responsible for repeat breeding syndrome. The cause of repeat breeding is multifaceted; most common causes are genetical, anatomical defects of the reproductive tracts, hormonal imbalances such as delay ovulation (Al-Timimi, et. al2001), infections such as clinical and subclinical endometritis and poor management (El-Khadrawy, H.H, et al., 2011). A multifactorial Problem involving a number of extrinsic factors coupled to the individual animal, could also be a cause (Abhijit. B. et al 2015)

A dministration of ( HCG 1500 I.U) 5 days after oestrus induces ovulation of the dominant follicle of first wave and formation of an accessory corpus luteum which increase the plasma progesterone level. In this way, it reduces the incidence of embryonic mortality (Pradeep K 2009).

Flunixin meglumine has been demonstrated to delay luteolysis and to support embryonic survival (Von Krueger , X and Heuwieser. 2010). Embryonic losses contribute considerably to low pregnancy rates. Between 8- 17 days after breeding, the conceptus secretes interferon as a mechanism for maternal recognition of pregnancy and maintenance of the corpus luteum.

Non steroid anti-inflammatory drugs inhibit the synthesis of prostaglandin F2a by

\begin{tabular}{|c|c|c|c|c|c|}
\hline Reproductive status & Treatment groups & $\mathbf{N}$ & Pregnant & Non pregnant & $\begin{array}{l}\text { Conception } \\
\text { rate \% }\end{array}$ \\
\hline \multirow{3}{*}{$\begin{array}{l}\text { Repeat } \\
\text { Breeding } \\
\text { cow } \\
\text { infertile }\end{array}$} & $\begin{array}{l}\text { T1 } \\
\text { HCG +HCG }\end{array}$ & 10 & 4 & 6 & $40.00 \%$ \\
\hline & $\begin{array}{l}\text { T2 } \\
\text { HCG +Flunxin }\end{array}$ & 10 & 6 & 4 & $60.00 \%$ \\
\hline & $\begin{array}{l}\text { C1 } \\
\text { Untreated control }\end{array}$ & 5 & 0 & 5 & $0.00 \%$ \\
\hline Fertile & $\begin{array}{l}\text { C2 } \\
\text { Control }\end{array}$ & 5 & 3 & 2 & $60.00 \%$ \\
\hline \multicolumn{2}{|l|}{ Chi-Square $\left(\chi^{2}\right)$} & -- & -- & -- & $13.297 * *$ \\
\hline
\end{tabular}

suppressing the enzyme cyclooxygenase( 16). pregnancy is associated with an increase in circulating progesterone concentration on 4-5 day after AI. One 
problem that may arise is asynchrony between mother and embryo (Merrill, M. L., R. P 2003).

\section{Materials and Methods}

1. Animals: The study's animal material comprised of 30 crossbreed cows, 25 of which were identified as having RBS and 5 of which were healthy. Farm records were used to identify repeat breeder cows. The study divided the number of animals into four groups, group $(10=\mathrm{T} 1)$, where the first group gave human chorionic gonadotropin on the day of oestrus and repeated the same dose 1500 IU Five days postinsemination and the group $(\mathrm{T} 2=$ 10) where the hCG hormone was given at a dose of $1500 \mathrm{IU}$ on the day of the estrus and Flunxin meglumine treatment with a dose $(2 \mathrm{ml} / 50 \mathrm{~kg} \mathrm{b.w})$ each ml contain to (50mg of FM) from the fifth day post insemination for three days and the third group, which numbered 5 cows in the group $(\mathrm{C} 1=5)$, were considered a control group without treatment, while the fourth group $(\mathrm{C} 2=5)$ is considered fertile cows, the purpose of their presence in the study is to evaluate the effectiveness of the fertility of the semen straws used in the study. . Early pregnancy was diagnosed rectally using ultrasound.

\section{Results}

Table (1): Conception rates in repeat breeding cows treated and untreated control group and fertile cows.

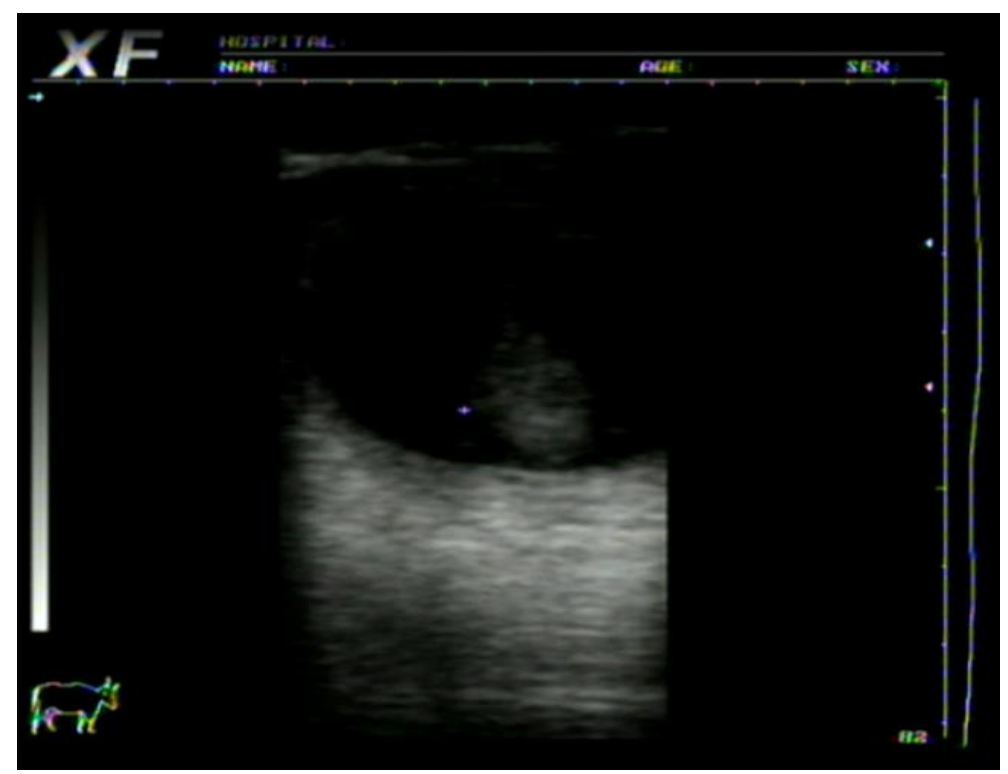

(Fetus at 45 day)

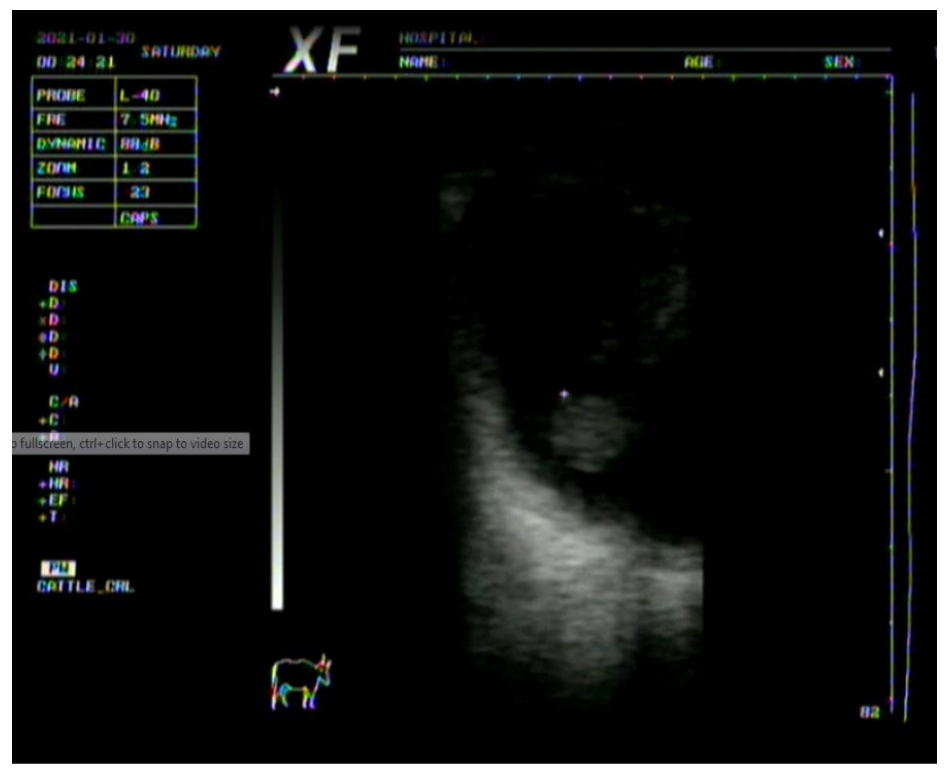

(Fetus at 60 day) 
University of Thi-Qar Journal of agricultural research

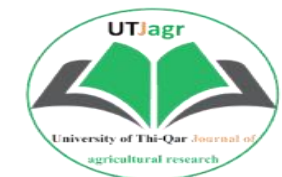

ISSN Onlin:2708-9347, ISSN Print: 2708-9339 Volume 10, Issue 2 (2021) PP 52-58

https://jam.utq.edu.iq/index.php/main https://doi.org/10.54174/UTJagr.Vo10.N2/01

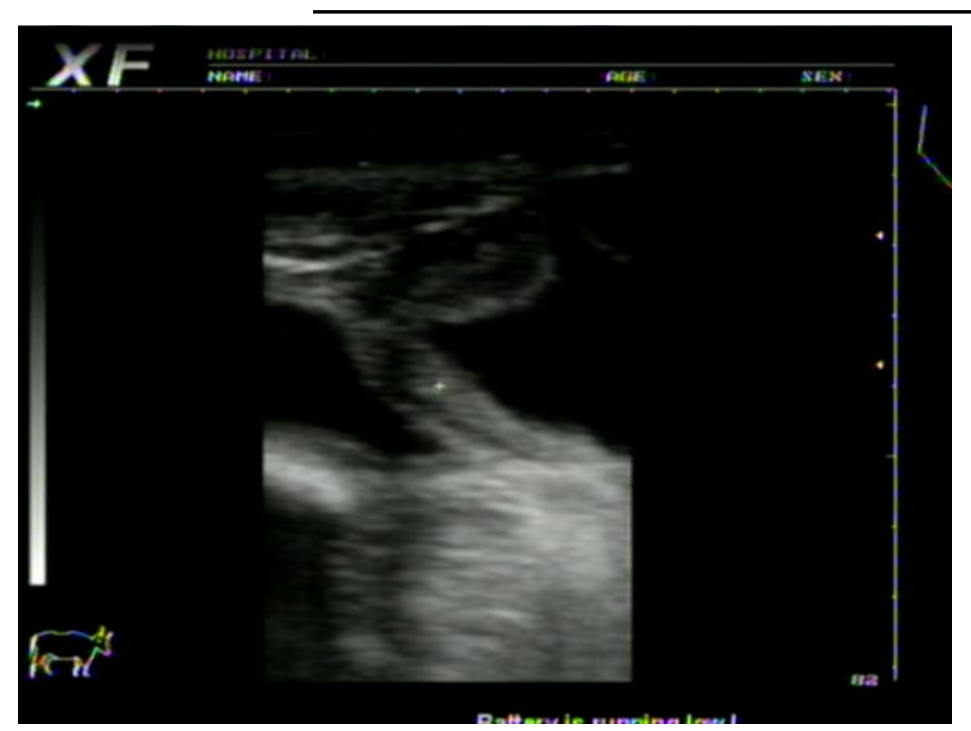

(Fetus at 105 days)

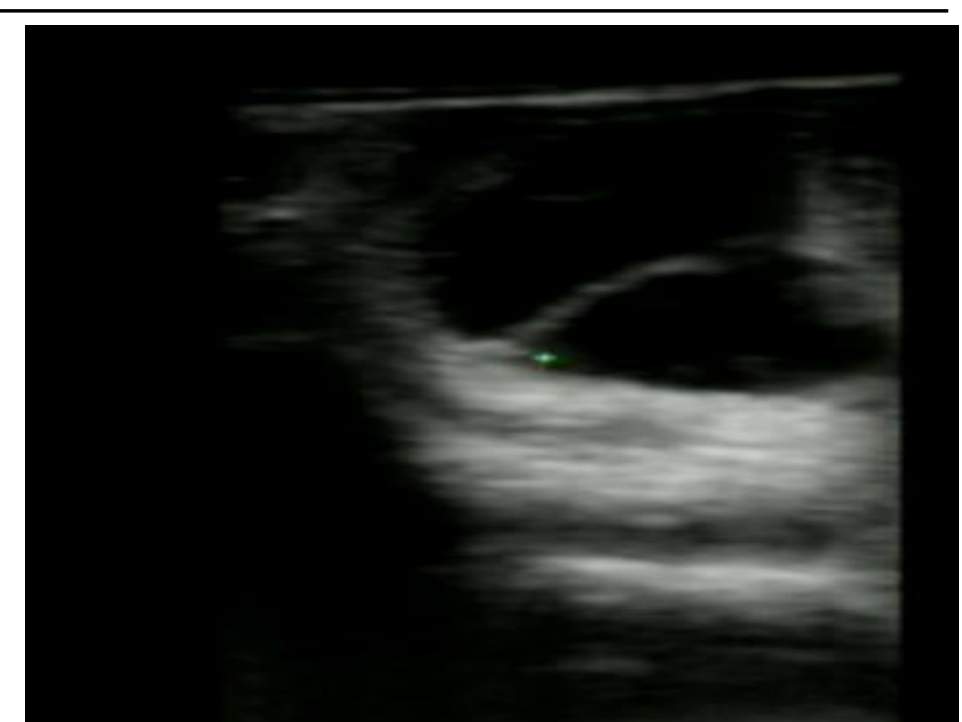

(Fetus at 90 days)
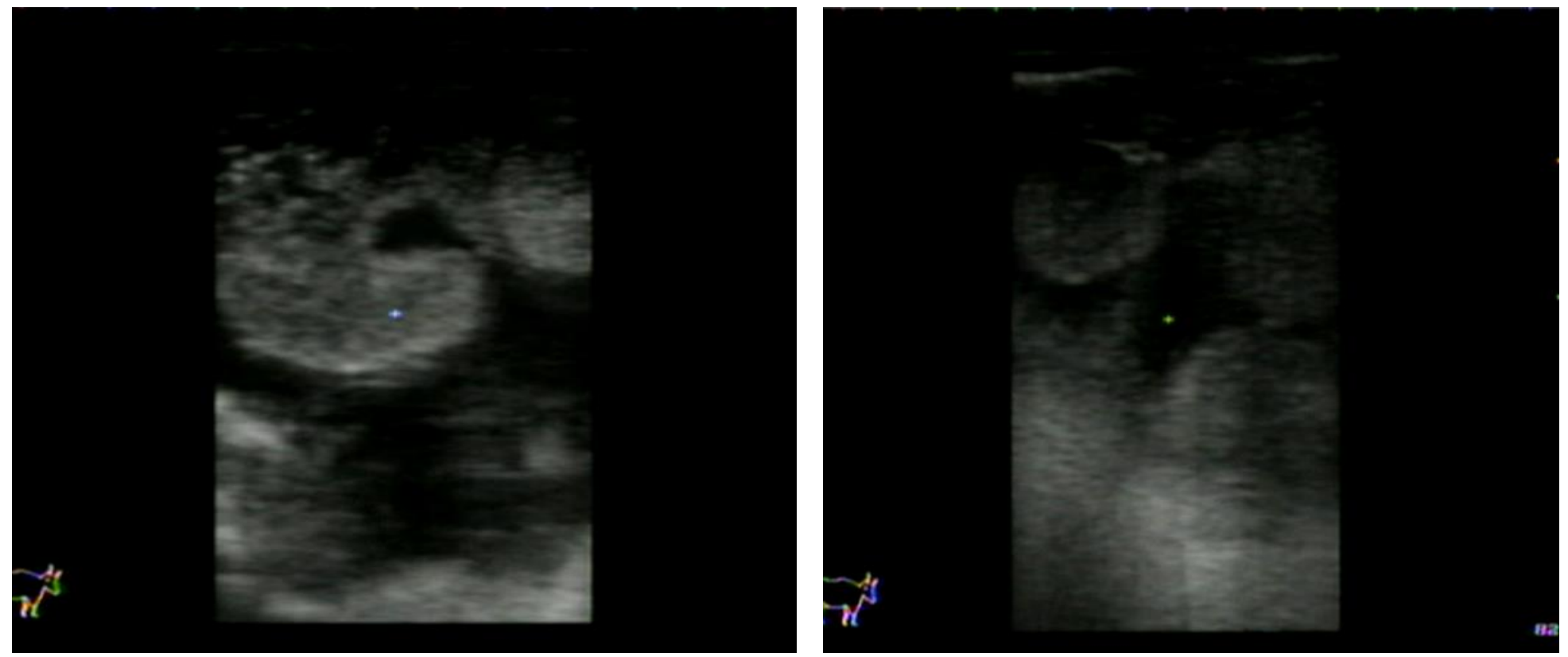

(Fetus at 90 days)

(Fetus at 90 days)
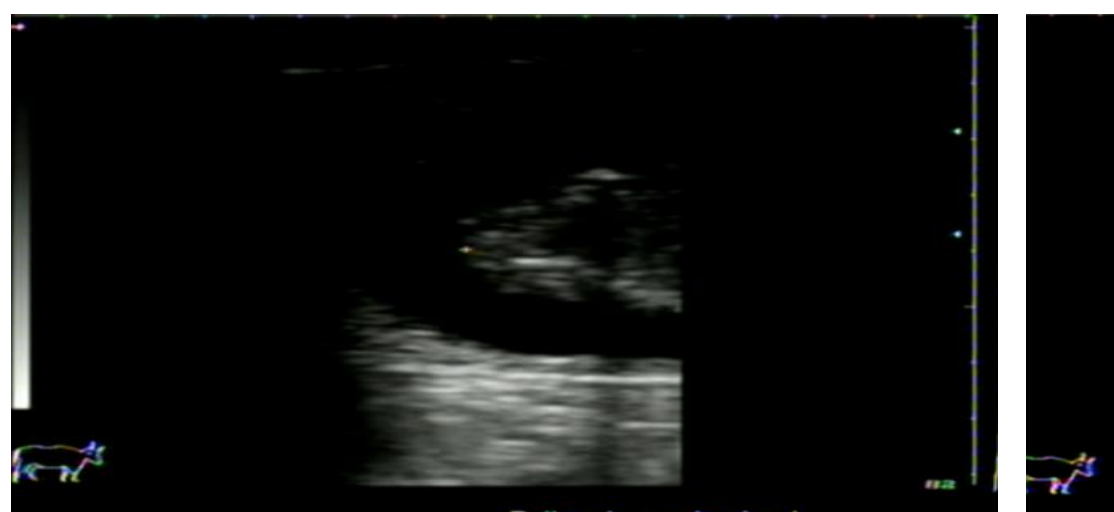


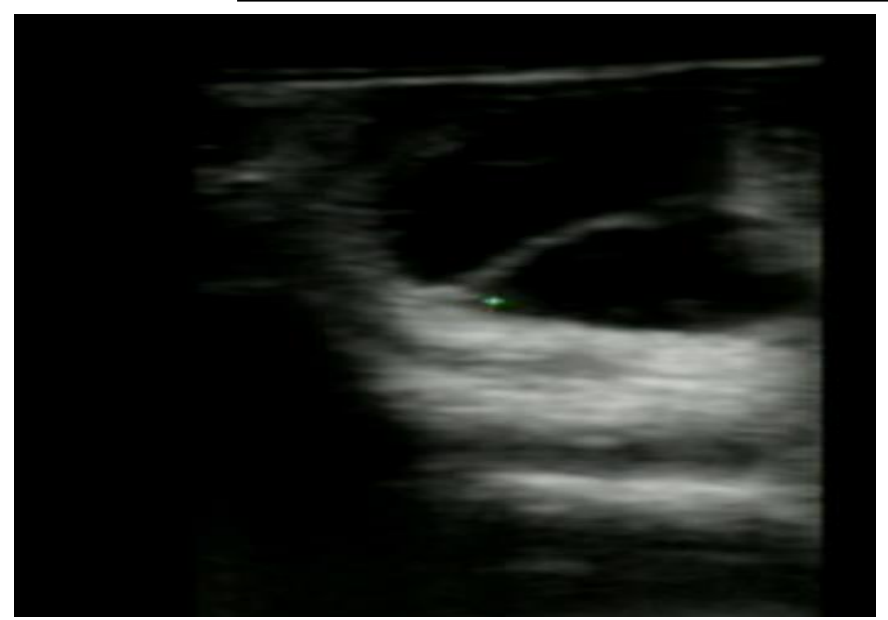

(Fetus at 90 days)

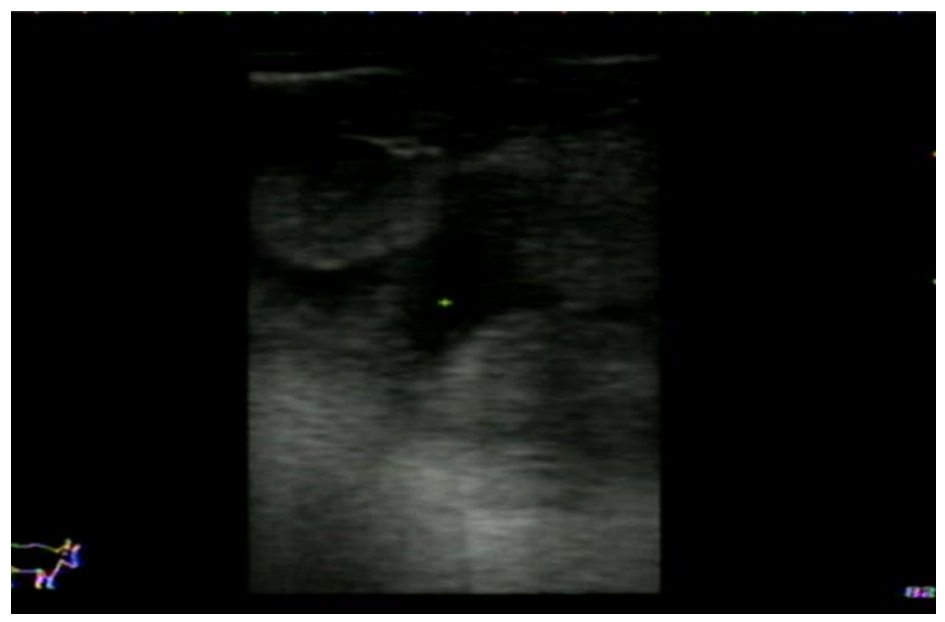

(Fetus at 30 days)

\section{IV.Discussions}

Results pertaining to fertile rate in repeat breeding cows are presented in table- 1 . The conception rates in T1, T2, C1 AND C2 were observed to be 40,60, 0 and $60 \%$ respectively. The conception rate was higher in $\mathrm{T} 2$ and $\mathrm{C} 2$, followed by $\mathrm{T} 1$ and zero in untreated control $\mathrm{C} 1$. The result were statistically significant between T1, T2, C2 and C1. The highest conception rate in T2. Kumar and purohit (2017) and Mathew et al.,(2013) found similar conception (45.45\% and 50\%) in repeat breeding cattle as in present study in group T1. However, Senthilkumar et al., (2017) and Patel et al., (2010) obtained higher conception rate $(73.33 \%$ and $83.30 \%)$ than the present experiment in group T1. Paksoy and Kalkan (2010) reported $46.70 \%$ conception rate in cows supplemented with hCG on day of estrus and $12^{\text {th }}$ day post insemination. Hernandezceron et al., (1993) stated that conception rate of repeat breeding heifers with delayed ovulation when treated with hCG at the time of insemination was lower $(26.70 \%)$ than treatment with double insemination only $(34.60 \%)$ or single insemination $(30.50 \%)$ without hCG treatment. Other studies in cattle had already reported positive effect of hCG treatment on pregnancy rates when it was given between days 4 and 7 post-AI Santos et .al (2001), Stevenson et .al (2007) and Sianangama and Rajamahendran (1992); this was attributed of hCG to increase progesterone plasma concentration (Santos et .al (2001) and Stevenson et .al (2007). it is well known that treatment with $\mathrm{GnRH}, \mathrm{LH}$, or hCG given between 4 and 7 days postestrus stimulates ovulation of the dominant follicle from the first wave of follicular growth, leading to the formation of an accessory corpus luteum Santos et .al (2001) and Nishigai et al (2002). Another activity associated with hCG is its ability to stimulate the original corpus luteum by acting on small and large luteal cells, Schmitt et al (1996) to result in greater progesterone output. It is well known that hCG has a longer half-life than GnRH or LH and a lower rate of dissociation from the ligand-receptor complex.

These result agreement with Kim et al. (2014) reported that the developmental rate of embryos was greater in cows that treated with the flunixin meglumine than in control cows. Also, Merrill et al.(2007) found that administration of FM in transported animals 
conjugated with increase in pregnancy rates comparaed to the control group(70\% vs, 59\%) Administration of flunxin meglumine in cows suffer from repeat breeders syndrome lead to increase in conceptus rate. Thatcher et al.(2001) suggested that embryonic loss may be due to some embryos fails to produce sufficient interferon tau to initiate maternal recognition of pregnancy approximately fourteen day after mating that inhibit uterine secretion of PGF2. Administration of flunxin meglumine to cows leads to decrease PGF2 concentration in the blood serum and increased the pregnancy rate(Merrill et al.(2007).

\section{References}

1 - Parkinson, T. J. 2001. Infertility. P. 463-464. In: Arthurs veterinary reproduction and obstetrics. $8^{\text {th }}$ ed. Noakes, D.E.;Parkinson, T.J. and England,G. C. W., eds. Saunders company, USA.

2-Al-Timimi I. H ; Khammas D. J. ; Al-Hamedawi T. M.(2001). Delayed Ovulation in Bovine: Diagnosis and Treatment. Vol.25 NO.1:Iraq.J. Vet. Med. 3 - El-Khadrawy, H.H., Ahmed, W.M., Emtenan, H.M. and Hanafi, E.M. (2011) Observations on repeat breeding in farm animals with emphasis on its control. $J$ Reprod. Fertil., 2(1): 01-07.

4 - Abhijit. B ., Subhasis , B ., Sarbaswarup , G ., Debjani ,S ., and Saibal C.(2015) : plasma mineral profiles and hormonal activites of normal cycling and repeat breeding crossbred cows : Acomparative study, Veterinary world, 8(1):42-45.

5- Foley GL (1996) Pathology of the corpus luteum of cows.Theriogenology 45: 14131428.

6 - Pradeep K (2009) : Applied veterinary gynecology and obstetrics. Published by international book distributing Co. P 212.

7 -Von Krueger, X and Heuwieser. (2010) : Effect of Flunixin meglumine and Carprofen on pregnancy rates in dairy cattle.J. Dairy Sci. 93:5140-5146.

8 - Green, M. P. M. G. Hunter, and G. E. Mann. 2005. Rleationships between maternal hormone secretion and embryo development on day 5 of pregnancy in dairy cows . Anim. Reprod. Sci. 88:179-189.

9- Merrill, M. L., R. P. Ansotegui, N. E. Wamsley, P. D. Burns, andT. W. Geary. 2003. Effects of flunixinmeglumine on embryonic loss in stressed beef cows. Proc. West. Sec. Am. Soc. Anim. Sci. 54:53-56.

10- Senthilkumar, A., P. Balamurugan, N. Sribalaji, G. Srinivasan and Murugesan, S. 2017. Hydroxy progesterone, human chorionic gonadotropin and GnRH analogue on fertility of repeat breeding dairy cattle in Theni district of Tamilnadu. Int. J. of Sci., Envi. And Tech., 6(1), 734- 737. 
11- Mathew, R., M. Aravinda, K. N. Ghosh, M. O. Kurien and Harshan, H. M, 2013. Comparison of Human placental extract, hCG and $\mathrm{GnRH}$ analogue on fertility of Repeat breeding cattle. Indian Vet. J, 90(4), 57-59.

12- Kumar, S. and Purohit, G. N. 2017. Effect of different hormonal therapies on day 5 of estrous on plasma progesterone profile and conception rates in repeat breeding dairy cows. J. Anim. Health Prod., 5(3), 103-106.

13- Patel, J. A., A. J. Dhami, F. S. Kavani, M. T. Panchal and Ghodasara, D. J. 2010. Indian. J. Anim. Repod., 31, 1.

14- Paksoy, Z., and Kalkan, C. 2010. The effects of GnRH and hCG used during and after artificial insemination on blood serum progesterone levels and pregnancy rate in cows. Kafkas Univ. Vet. Fak. Derg., 16(3),

15- Hernandezceron, J., L. Zarco and Lima, T. V. 1993. Theriogenology, 40, 1073. Holtemoller, B. 1981. Investigation on the use of synthetic GnRH in cattle. Abstr. Anim. Breed., 49, 1259.

$371-375$.

16- Santos JE, Thatcher WW, Pool L, Overton MW. Effect of human chorionic gonadotropin on luteal function and reproductive performance of high producing lactating Holstein dairy cows. J Anim Sci 2001; 79:2881-94.

17- Stevenson JS, Portaluppi MA, Tenhouse DE, LIoyed A, Eborn DR, Kacuba S, et al . interventions after artificial insemination: conception rates, pregnancy survival, and ovarian responses to gonadotropin-releasing hormone, human chorionic gonadotropin, and progesterone. J Dairy Sci 2007 ; 90:331-40.

18- Sianangama PC, Rajamahendran R. Effect of human chorionic gonadotropin administereted at specific times following breeding on milk progesterone and pregnancy in cows. Theriogenology 1992;38:85-96.

19- Nishigai M, Kamomae H, Tanaka T, Kaneda Y. Improvemwent of pregnancy rate in Japanese Black cows by administration of hCG to recipients of transferred frozen-thawed embryos. Theriogenolgy 2002; 58:1597-606.

20- Schmitt EJ, Diaz T, Barros CM, de la sorta RL, Drost M, Ferdriksson EW, et al. Differential response of the luteal phase and fertility in cattle following ovulation of the first wave follicle with human chorionic gonadotropin or an agonist of gonadotropin releasing hormone. J Animal Sci 1996; 74:107483. 
University of Thi-Qar Journal of agricultural research

ISSN Onlin:2708-9347, ISSN Print: 2708-9339 Volume 10, Issue 2 (2021) PP 52-58

https://jam.utq.edu.iq/index.php/main https://doi.org/10.54174/UTJagr.Vo10.N2/01

21- Kim,S.S,;J.I. Bang; M. Fakruzzaman; k. L, Lee; D.H.Ko;N.Ghanem;Z. Wang and I.K.Kong(2014).Effect of flunxin on the development and quality of bovine embryos in vitro. Reprod Dom Animal 49:957-963.

22- Merrill, M.L.;R.P. Ansotegui; P. D. Burns; M.D. MacNeil and T.W. Geay (2007). Effect of flunixin meglumine and transportation on establishment of pregnancy in beef cows. J Animal. Sci., 85:1547-1554.

23- Thatcher, W. W.;A. Guzeloglu; R. Mattos; M. Binelli; T.R. Hansen and J.K. Pru (2001). Uterine-conceptus interactions and reproductive failure in cattle. Theriogenolgy, 56: $1435-1450$. 